\title{
FIRST NOTICE OF PHYTOPHTHORA CROWN AND ROOT ROT OF EUPHORBIA PULCHERRIMA IN POLISH GREENHOUSES
}

\author{
Leszek B. Orlikowski*, Magdalena Ptaszek
}

Research Institute of Horticulture, Konstytucji 3 Maja Street 1/3, 96-100 Skierniewice, Poland

Received: February 26, 2013

Accepted: September 26, 2013

\begin{abstract}
The plant pathogen, Phytophthora cryptogea, was recovered from 4/5 of the 75 poinsettias collected from two greenhouse farms. The poinsettias showed stunting and wilting as well as stem base and root rot symptoms. Representative isolates of the species from two poinsettia cultivars, colonized stem parts, leaf petioles, leaf blades and root parts. Stem parts of 6 cultivars were colonized at a slower rate than other poinsettia organs. Isolate from Euphorbia pulcherrima also colonized stem parts and leaf blades of E. amygdaloides, E. cyparissias, and E. polychroma. Isolates of P. cryptogea from the other 6 plant hosts, colonized the overground parts of poinsettia cv. Allegro. This is the first report describing symptoms and colonization of poinsettia cultivars by P. cryptogea in Poland.
\end{abstract}

Key words: Euphorbia pulcherrima, colonization, cultivars, occurrence, Phytophthora cryptogea, symptoms

\section{INTRODUCTION}

There are several diseases caused by leaf and soilborne pathogens which affect poinsettia production. Benson et al. (2002) mentioned Alternaria blight (Alternaria euphorbiicola E.G. Simmons \& Engelhard), gray mold (Botrytis cinerea Pers.), powdery mildew (Oidium sp.), scab (Sphaceloma poinsettiae Jenk. and Ruehle), Erwinia blight (Pectobacterium carotovorum Jones), Xanthomonas leaf spot (Xanthomonas campestris pv. poinsettiicola (Patel, Bhatt \& Kulkarni), Pythium root rot (Pythium aphanidermatum (Edson) Fitzp., P. irregulare Buisman), Rhizoctonia stem rot (Rhizoctonia solani Kuhn), and black root rot (Thielaviopsis basicola Berk. and Broome). Additionally, Orlikowski et al. (2007) reported Fusarium stem rot and dieback of poinsettia caused by F. oxysporum Schlecht. The occurrence of Phytophthora crown and stem rot of poinsettia caused by Phytophtora nicotianae Breda de Haan var. parasitica (Dastur) in the USA, was described by Engelhard et al. (1979). Six years later, Yoshimura et al. (1985) reported the blight of poinsettia leaves, bracts and cyathia caused by the already mentioned species and P. drechsleri Tucker. Ann (1992) isolated P. parasitica from diseased roots of plants grown in Taiwan, but also mentioned P. cryptogea Pethybr. et Laff. In Japan, Kanto (2007) described Phytophthora blight incited by P. nicotianae whereas Lamour et al. (2003) noticed P. drechsleri on diseased poinsettia parts in Florida, USA. De Jensen et al. (2006) reported wilt and stem canker of poinsettia (P. nicotianae) growing in Puerto Rican greenhouses. In about half of the surveyed farms, the disease severity ranged from 5 to $100 \%$, regardless of whether mefanoxam was used for plant protection or not. Recorded symptoms included stunted plants, thin stems, chlorotic leaves, and brown-rot bract development. Leaves of affected plants wilted because of stem canker.

The attractiveness and continuing popularity of poinsettia in Poland during the Christmas season creates a high seasonal demand for this crop. At the end of summer and autumn 2010, wilting and dieback was observed on potted poinsettia cuttings and older plants growing in two greenhouses. On a few weeks old cuttings of cvs. Allegro and Saturnus Red, grown separately in two greenhouses, discoloration and wilting of leaf blades were observed. On the base of the stems, brown or dark brown spots were noticed. The spots were first on one side and then extended around the stems. Root tips were turning brown and dying on all plants. During the next 10 days, poinsettias up to $30 \mathrm{~cm}$ high, had their single shoots wilt or all of them wilt. Stem base rot extended upwards even to $10 \mathrm{~cm}$, and necrosis spread on leaf petioles and blades. Most of the roots were brown or dark brown. At both farms, the disease severity ranged from about 7 to $10 \%$.

The aim of our study was to isolate, identify, and estimate the pathogenicity of the causal agent of poinsettia dieback.

\section{MATERIALS AND METHODS}

\section{Laboratory analysis of diseased plants}

Seventy-five plants at different stages of development were collected from two greenhouses. In the first object (ST), poinsettias, with 'Allegro' as the main cultivar, were grown on about $20000 \mathrm{~m}^{2}$, whereas in the second (RS) on an area of $7000 \mathrm{~m}^{2}$ with cv. Saturnus Red as the main cultivar (about $60 \%$ of growing plants). Plant samples to- 
gether with peat substratum were transferred in plastic bags to the laboratory. The procedure described by Orlikowski and Szkuta (2002) was used to isolate microorganisms from the diseased poinsettia tissues. Plants stem parts and roots were washed under running tap water and later with distilled water. Next, they were blotted dry and sterilized over a burner flame. Plant parts, which were about $5 \mathrm{~mm}$ in diameter were taken from the border of healthy and diseased stems tissues and transferred into Petri dishes (90-mm diameter) containing PDA (Potato Dextrose Agar). After $48 \mathrm{~h}$ of incubation at $25^{\circ} \mathrm{C}$ in the dark, small actively growing plugs of Phytophthora mycelium were transferred onto PDA slants. The slants were stored in the dark at $25^{\circ} \mathrm{C}$, in the laboratory incubator.

\section{Identification of isolates}

Representative isolates were identified by morphological and cultural characteristics (Erwin and Ribeiro 1996). Identification was confirmed by PCR, with speciesspecific primers (Boersma et al. 2000; Minerdi et al. 2008).

\section{Analysis of substratum for the presence of Phytoph- thora sp.}

Substratum taken from poinsettia pots with disease symptoms, were also sampled for the occurrence of Phytophthora spp. by soil baiting technique using rhododendron leaves cv. Nova Zembla (Orlikowski and Ptaszek 2010). Leaves were laid in $10 \mathrm{~mm}$ of standing water, on the surface of the flooded substratum, in photographic tray $(30 \times 25 \times 5 \mathrm{~cm})$ at $22-24^{\circ} \mathrm{C}$. After a 4 day-incubation, the leaves were removed, rinsed in tap water, and distilled water, blotted dry, and sterilized over a burner flame. The parts, which were about $5 \mathrm{~mm}$ in diameter, were transferred onto PDA. The rest of the procedure was similar to that done with the isolation and identification of Phytophthora spp. from diseased poinsettias.

\section{Pathogenicity tests}

\section{Cultures}

Isolates of Phytophthora cryptogea from diseased stembases of cvs. Allegro and Saturnus Red, and additionally from 6 other plant species growing under cover and in the field were chosen for further studies. Cultures were maintained on PDA at $25^{\circ} \mathrm{C}$ in the dark. For inoculation of plant parts, $3 \mathrm{~mm}$ in diameter plugs of medium which were overgrown by Phytophthora isolates and taken from the edge of 7-day-old cultures, were used.

\section{Plant species and cultivars}

Euphorbia amygdaloides, E. cyparissias, E. polychroma, E. pulcherrima and cultivars Allegro, Cristalo, Ice Punch, Peter Star Red, Poinsettia Pink, and Saturnus Red were used for the inoculation trials with $P$. cryptogea to estimate them as potential source of the pathogen.

\section{Inoculation}

About $5 \mathrm{~cm}$ long stem parts, leaf petioles, leaf blades and root parts were transferred to trays having sterile, moist, blotting paper covered with thin plastic net to keep plants over the blotting paper. Phytophthora inocula were put on the bases of stem parts and roots as well as on the centre part of leaf blades. Then the trays were covered with thin foil. After a 5-7 day incubation, the length and diameter of necrosis were measured.

\section{Greenhouse trial}

Phytophthora cryptogea isolates obtained from the affected stem base of poinsettia, and substratum from the diseased plants were used for peat infestation. Cultures were grown on PDA medium in $90 \mathrm{~mm}$ Petri dishes at $25^{\circ} \mathrm{C}$. Five $\mathrm{mm}$ in diameter discs overgrown by P. cryptogea, were taken from the edge of 7-day-old cultures and transferred onto Petri dish plates with rolled oats (Orlikowski 1999). After a 2 -week-incubation at $25^{\circ} \mathrm{C}$, cultures were blended with $150 \mathrm{ml}$ of sterilised water in a Waring Blender to form a thick slurry. The homogenates were mixed with peat at a ratio of one plate per $1 \mathrm{dm}^{3}$ of peat. After infested peat was stored in plastic bags for 10 days, the population density of P. cryptogea was measured using the method of Flowers and Hendrix (1969). By dilution of infested peat with uninfested substratum, the population density was assayed on the level of 350 colonyforming units/g of air dry substratum. Peat infested with both isolates of $P$. cryptogea and uninfested substratum (the control), were poured into $1 \mathrm{dm}^{3}$ pots, and rooted poinsettia cuttings (cv. Allegro) were planted. Plants were cultivated on greenhouse benches at temperatures which ranged from 17 to $26^{\circ} \mathrm{C}$ for 10 weeks. At 2 week-intervals, number of plants showing disease symptoms were noted.

\section{Statistical analyses}

The experimental design was completely randomized with 4 replications and 5 plant parts and 10 cuttings in each replication. Trials were repeated twice, at 2 week intervals. The obtained results were elaborated using an analysis of variance. Significant treatment differences were evaluated by Duncan's multiple range test $(p=0.05)$.

\section{RESULTS}

\section{Pathogens occuring on poinsettia plants}

From 40 of the analysed, diseased plant parts, collected from farm ST, 32 of them yielded P. cryptogea. Additionally, Alternaria alternata Ness, Botrytis cinerea Pers., Cladosporium herbarum Link., Mucor spp., Penicillium spp. were detected from diseased tissues.

Among 35 poinsettias showing stem base rot and wilt symptoms, collected from greenhouse RS, P. cryptogea was recovered from 28 of cv. Saturnus Red. Besides the already mentioned species, Fusarium avenaceum (Cda) Sacc., Pythium ultimum Trow and Trichoderma spp. were isolated.

\section{Pathogenicity of $P$. cryptogea isolates}

The first laboratory inoculation trial was done with 4 poinsettia (E. pulcherrima) cultivars from the ST farm using isolate from cv. Allegro (Table 1). The culture colonised all parts of the poinsettias. After a 7-day-incubation, necrosis spread much faster on leaf blades (33.1-49.5 $\mathrm{mm}$ ) and roots (32.1-44.5 $\mathrm{mm}$ ) than on stem parts $(21.9-34.6 \mathrm{~mm})$. 
Table 1. Relationship between poinsettia cultivars and colonization of plant parts by P. cryptogea isolate from cv. Allegro; length/ diameter of necrosis $(\mathrm{mm}) 7$ days after inoculation

\begin{tabular}{lcccc}
\hline \multicolumn{1}{c}{ Cultivars } & Stem parts & Roots & Leaf blades & Leaf petioles \\
\hline Allegro & $33.9 \mathrm{~b}$ & $34.9 \mathrm{a}$ & $49.5 \mathrm{~b}$ & $39.0 \mathrm{~b}$ \\
Cristalo & $21.9 \mathrm{a}$ & $32.1 \mathrm{a}$ & $33.1 \mathrm{a}$ & $31.1 \mathrm{a}$ \\
Ice Punch & $34.6 \mathrm{~b}$ & $44.5 \mathrm{~b}$ & $44.7 \mathrm{~b}$ & $36.7 \mathrm{~b}$ \\
Peter Star Red & $29.8 \mathrm{~b}$ & $43.0 \mathrm{~b}$ & $44.0 \mathrm{~b}$ & $44.6 \mathrm{c}$ \\
\hline
\end{tabular}

Means in columns, followed by the same letter, do not differ significantly at the $5 \%$ level according to Duncan's multiple range test

The largest differences in the rate of necrosis development were observed on leaf petioles. The spread of necrosis was from 31.1 to $44.6 \mathrm{~mm} / 7$ days. Cultivar Cristalo was significantly less susceptible than other tested cultivars (Table 1).

Inoculation of 6 cultivars of poinsettia organs by two isolates of P. cryptogea from cvs. Allegro and Saturnus Red, resulted in the colonization of all of them (Table 2). Stem parts were more resistant to infection than leaf petioles and leaf blades, probably due to degree of tissue suberisation. Additionally, isolate from cv. Allegro was more pathogenic toward stem parts than those from cv. Saturnus Red (Table 2). The obtained results indicated that different poinsetia cultivars are very susceptible to $P$. cryptogea, and also showed that all commercially growing cultivars may be the source of the pathogen.

In the root inoculation trials, two tested P. cryptogea isolates caused necrosis on abscised roots. The analysis of the colonization of root parts of cvs. Peter Star Red and Saturnus Red by the tested isolates, indicated that there was a small difference or a lack of differences in tissues colonization. Necrosis development was about $8 \mathrm{~mm} / 24 \mathrm{~h}$ (Fig. 1).
Inoculation of 4 Euphorbia species, including E. pulcherrima, by P. cryptogea isolate from cv. Allegro, resulted in the development of necrosis, on stem parts and leaf blades (Table 3). The quickest spread of disease symptoms was observed on stem parts of E. amygdaloides, whereas the slowest was observed on E. cyparissias. Furthermore, the leaf blades of E. pulcherrima were the most susceptible to the tested isolate (Table 3 ). These results indicated that different plant species belonging to the Euphorbiaceae family are highly susceptible to P. cryptogea, and they could also be a source of that pathogen.

In pathogenicity trials with $P$. cryptogea isolates from 7 different host plants, all tested cultures were able to infect (Table 4) overground parts of poinsettia cv. Allegro. Isolates from Gerbera jamesonii and Lycopersicum esculentum were weaker colonizers of poinsettia organs than others. The quickest spread of disease was observed after inoculation of tissues by isolates from E. pulcherrima, Saxifraga paniculata, and Sempervivum arachnoideum. In general, stem parts were colonized more slowly than the other tested poinsettia organs. After 7 days of incubation, the length of necrosis was between $12.4-34.1 \mathrm{~mm}$, whilst on leaf petioles 18.5-42.5 mm, and on leaf blades 24.4-53.5 mm (Table 4).

Table 2. Relationship between source of P. cryptogea isolates, E. pulcherrima cultivars, and colonization of plant parts; length/diameter of necrosis $(\mathrm{mm}) 7$ days after inoculation

\begin{tabular}{lcccccc}
\hline \multirow{2}{*}{ Cultivars } & \multicolumn{3}{c}{ Isolate from cv. Allegro } & \multicolumn{3}{c}{ Isolate from cv. Saturnus Red } \\
\cline { 2 - 7 } & stem parts & leaf petioles & leaf blades & stem parts & leaf petioles & leaf blades \\
\hline Allegro & $31.1 \mathrm{~d}-\mathrm{f}$ & $43.0 \mathrm{c}$ & $45.8 \mathrm{~cd}$ & $21.9 \mathrm{a}-\mathrm{c}$ & $43.5 \mathrm{c}$ & $39.8 \mathrm{a}-\mathrm{c}$ \\
Cristalo & $24.7 \mathrm{c}$ & $43.5 \mathrm{c}$ & $44.5 \mathrm{~cd}$ & $17.7 \mathrm{a}$ & $44.5 \mathrm{c}$ & $35.5 \mathrm{a}$ \\
Ice Punch & $33.5 \mathrm{ef}$ & $41.9 \mathrm{bc}$ & $43.5 \mathrm{~b}-\mathrm{d}$ & $19.3 \mathrm{ab}$ & $39.9 \mathrm{bc}$ & $42.4 \mathrm{bc}$ \\
Peter Star Red & $26.8 \mathrm{~cd}$ & $46.0 \mathrm{c}$ & $49.0 \mathrm{~d}$ & $23.2 \mathrm{a}-\mathrm{c}$ & $45.4 \mathrm{c}$ & $37.6 \mathrm{ab}$ \\
Poinsettia Pink & $34.8 \mathrm{f}$ & $30.8 \mathrm{a}$ & $45.7 \mathrm{~cd}$ & $32.6 \mathrm{ef}$ & $35.8 \mathrm{ab}$ & $42.0 \mathrm{bc}$ \\
Saturnus Red & $33.8 \mathrm{e}-\mathrm{g}$ & $32.8 \mathrm{a}$ & $43.5 \mathrm{~b}-\mathrm{d}$ & $30.9 \mathrm{de}$ & $44.2 \mathrm{~cd}$ & $49.3 \mathrm{~d}$ \\
\hline
\end{tabular}

Means in columns, followed by the same letter, do not differ significantly at the $5 \%$ level according to Duncan's multiple range test

Table 3. Colonisation of Euphorbia spp. parts by P. cryptogea isolate from E. pulcherrima cv. Allegro; length/diameter of necrosis (mm) 7 days after inoculation

\begin{tabular}{lcc}
\hline \multicolumn{1}{c}{ Euphorbia species } & Stem part & Leaf blades \\
\hline E. amygdaloides & $22.2 \mathrm{c}$ & $20.0 \mathrm{~b}$ \\
E. cyparissias & $7.1 \mathrm{a}$ & $13.3 \mathrm{a}$ \\
E. polychroma & $13.9 \mathrm{~b}$ & $16.3 \mathrm{a}$ \\
E. pulcherrima & $14.4 \mathrm{~b}$ & $29.9 \mathrm{c}$ \\
\hline
\end{tabular}

Means in columns, followed by the same letter, do not differ significantly at the $5 \%$ level according to Duncan's multiple range test 


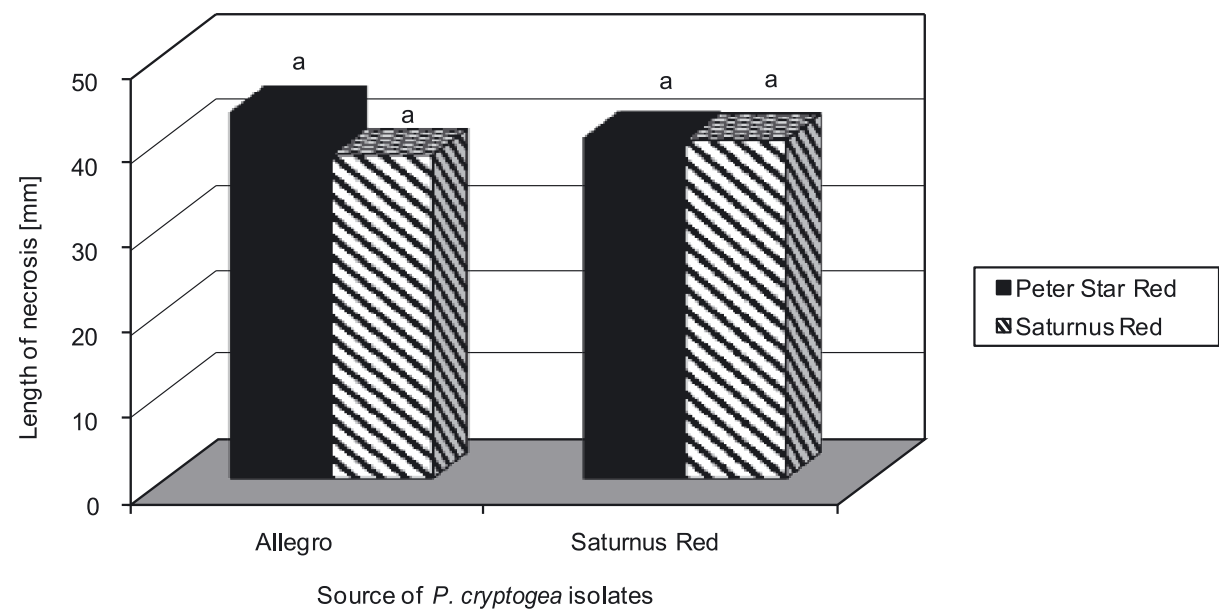

Fig. 1. Relationship between source of $P$. cryptogea isolates, poinsettia cultivars, and colonisation of roots 5 days after inoculation Means in columns, followed by the same letter, do not differ significantly at the $5 \%$ level according to Duncan's multiple range test

Table 4. Relationship between source of P. cryptogea and colonisation of poinsettia parts by isolates from different host plants; length/ diameter of necrosis $(\mathrm{mm}) 7$ days after inoculation

\begin{tabular}{lccc}
\hline \multicolumn{1}{c}{ Source of isolates } & Stem parts & Leaf petioles & Leaf blades \\
\hline Alstroemeria $\times$ hybrida & $17.9 \mathrm{~b}$ & $34.2 \mathrm{bc}$ & $23.4 \mathrm{a}$ \\
Euphorbia pulcherrima & $34.1 \mathrm{~d}$ & $36.7 \mathrm{~cd}$ & $53.5 \mathrm{~d}$ \\
Forsythia intermedia & $14.9 \mathrm{ab}$ & $29.8 \mathrm{~b}$ & $36.4 \mathrm{~b}$ \\
Gerbera jamesonii & $14.1 \mathrm{ab}$ & $18.5 \mathrm{a}$ & $24.4 \mathrm{a}$ \\
Lycopersicum esculentum & $12.4 \mathrm{a}$ & $30.7 \mathrm{~b}$ & $25.8 \mathrm{a}$ \\
Saxifraga paniculata & $32.8 \mathrm{~d}$ & $40.5 \mathrm{de}$ & $47.3 \mathrm{c}$ \\
Sempervivum arachnoideum & $28.4 \mathrm{c}$ & $42.5 \mathrm{e}$ & $52.6 \mathrm{~d}$ \\
\hline
\end{tabular}

Means in columns, followed by the same letter, do not differ significantly at the $5 \%$ level according to Duncan's multiple range test

\section{Greenhouse trial}

Transplanting of rooting poinsettia cuttings into peat infested with $P$. cryptogea from the diseased plant, resulted in the sporadic occurrence of stem base rot symptoms after a 2-week-growth period (Fig. 2). Within the next 8 weeks, wilting of plants and development of stem ne- crosis on the base was observed on poinsettia grown in peat infested with both isolates. After a 10 week-growth period, about 7/10 plants were affected by $P$. cryptogea. Statistical analysis showed the lack of significant differences between the pathogenicity of tested isolates in all observation periods (Fig. 2).

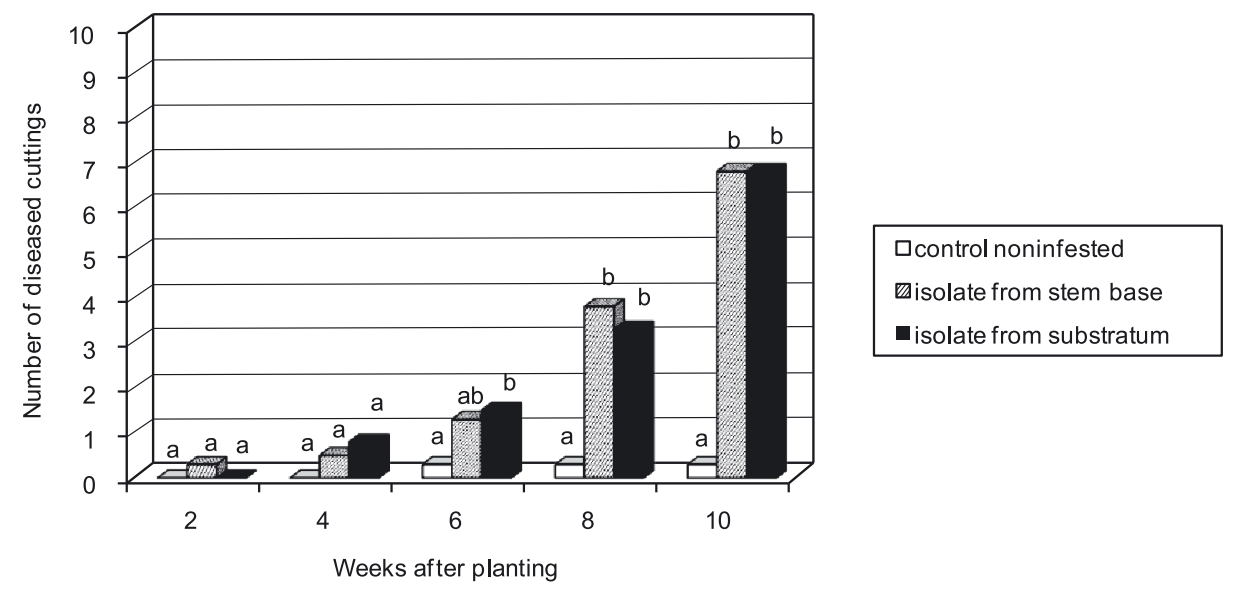

Fig. 2. Relationship between source of P. cryptogea isolates, growing period, and healthiness of poinsettia cuttings cv. Allegro. Means in columns, followed by the same letter, do not differ significantly at the $5 \%$ level according to Duncan's multiple range test 


\section{DISCUSSION}

Results obtained during this study showed that besides F. oxysporum (Orlikowski et al. 2007), P. cryptogea presents a serious threat for poinsettia growers as well. Further studies which deal with the possibility of its control are necessary. Phytophtora cryptogea dominated among 9 genera and species isolated from 75 diseased stem bases of E. pulcherrima. The species settled $4 / 5$ of poinsettias in both greenhouses whereas other fungal species occurred rarely or sporadically. It is possible that $B$. cinerea and $F$. avenaceum, known as plant pathogens, colonized weakened tissues of poinsettia infected already by $P$. cryptogea. In both greenhouse farms, transplanting of young rooted poinsettias to new pots and fresh peat substratum, resulted in the occurrence of disease symptoms. Stem base rot and wilting symptoms, mainly on cv. Allegro in one farm and cv. Saturnus Red in the other, indicated that these cultivars were the primary sources of $P$. cryptogea brought to greenhouse farms. Other cultivars grown at both farms, did not show any disease symptoms. The indication was that $P$. cryptogea was brought in on rooting cuttings.

Symptoms observed on affected poinsettias were similar to those described for diseases caused by P. cryptogea on other ornamental plants (Daughtrey et al. 1995). The symptoms include stunt, wilt, chlorosis, stem base and root necrosis. Ann (1992) detected this species from diseased poinsettia roots in Taiwan, but did not study its pathogenicity. Our results from pathogenicity trials of the mentioned species to 6 poinsettia cultivars indicated that, till now, there are no resistant varietes on the market. For this reason, the data may be an important indication for poinsettia breeders to include in a breeding programme new cultivars, which are resistant to $P$. cryptogea and other species from that genera.

Preliminary tests demonstrated that $P$. cryptogea isolates recovered from 7 different plant species are not only restricted to their hosts but exhibited a wide range of activity. All of them colonized poinsettia and also other species, but significant differences in their pathogenicity was noticed on particular plant parts. Studies of Orlikowski and Ptaszek $(2007 ; 2008 ; 2010)$ and Ptaszek and Orlikowski (2010) showed the colonization of new host plants, including bushes and perennials, by that species. A wide plant range of $P$. cryptogea was described earlier by Erwin and Ribeiro (1996), but during the last 20 years the number of hosts increased by at least $30 \%$. These new hosts could be the source of $P$. cryptogea for horticultural plants, including E. pulcherrima. This study indicated Euphorbia spp. as the next hosts for P. cryptogea. This is the first report describing the disease caused by that pathogen on E. pulcherrima in Polish greenhouses and probably in other European countries.

\section{REFERENCES}

Ann P.-J. 1992. New diseases and records of some important flower plants caused by Phytophthora parasitica in Taiwan. Plant Pathol. Bull. 1: 166-173.

Benson D.M., Hall J.L., Moorman G.W., Daughterey M.L., Chase
A.R., Lamour K.H. 2002. The history and diseases of poinsettia, the Christmas flower. Plant Health Prog.: 1-19.

Boersema J.G., Cooke D.E.L., Sivasithamparam K. 2000. A survey of wildflower farms in the south-west of Western Australia for Phytophthora spp. associated with root rot. Aust. J. Exp. Agric. 40 (7): 1011-1019.

De Jensen C.E., Abad G., Roberts P., Rosa E. 2006. First report of wilt and stem canker of poinsettia (Euphorbia pulcherrima) caused by Phytophthora nicotianae in Puerto Rico. Plant Dis. 90 (11): 1459.

Daughtrey M.L., Wick R.L, Peterson J.L. 1995. Compendium of Flowering Potted Plant Diseases. APS Press, St Paul, Minnesota, $90 \mathrm{pp}$.

Engelhard A.W., Ploetz R.C. 1979. Phytophthora crown and stem rot, an important new disease of poinsettia (Euphorbia pulcherrima). Proc. Fla. State Hort. Soc. 92: 348-350.

Erwin D.C., Ribeiro O.K. 1996. Phytophthora Diseases World Wide. APS Press, St Paul, Minnesota, 562 pp.

Flowers R.A., Hendrix H.W. 1969. Gallic acid in a procedure for isolation of Phytophthora parasitica var nicotianae and Pythium spp. from soil. Phytopathology 59 (6): 725-731.

Kanto T. 2007. Phytophthora blight of poinsettia (Euphorbia pulcherrima Willd. ex Klotzsch.) caused by Phytophthora nicotianae Breda de Haan (1986). Japanese J. Phytopathol. 73 (2): 112-113.

Lamour K.H., Daughtrey M.L., Benson D.M., Hwang J., Hausbeck M.K. 2003. Etiology of Phytophthora drechsleri and P. nicotianae (=P. parasitica) diseases affecting floriculture crops. Plant Dis. 87 (7): 854-858.

Minerdi D., Moretti M., Li Y., Gaggero L., Garibaldi A., Gullino M.L. 2008. Conventional PCR and real time quantitative PCR detection of Phytophthora cryptogea on Gerbera jamesonii. Eur. J. Plant Pathol. 122 (2): 227-237.

Orlikowski L.B. 1999. Selective medium for the evaluation of biocontrol agent efficacy in the control of soilborne pathogens. Bull. Pol. Acad. Sci. Biol. Sci. 47 (2-4): 167-172.

Orlikowski L.B., Ptaszek M. 2007. Phytophthora species in Polish ornamental nurseries. I. Perennial plants, new hosts of $P$. cryptogea. J. Plant Prot. Res. 47 (4): 401-408.

Orlikowski L.B., Ptaszek M. 2008. Phytophthora cryptogea and P. citrophthora; new pathogens of Forsythia intermedia in Polish ornamental hardy nursery stocks. J. Plant Prot. Res. 48 (4): 495-501.

Orlikowski L.B., Ptaszek M. 2010. Gatunki Phytophthora jako przyczyna zamierania żywotników (Thuja spp.) w polskich szkółkach kontenerowych. [Phytophthora species as the causal threats of Sorbus aucuparia in Poland]. Sylwan 154 (4): 242-248.

Orlikowski L.B., Skrzypczak Cz., Valiuskaite A., Sroczyński M. 2007. Fuzaryjna zgnilizna - nowa choroba poinsecji w Polsce. [Fusarium rot - New disease of Poinsttia in Poland]. Post. Ochr. Roślin/Prog. Plant Prot. 47 (2): 212-215.

Orlikowski L.B., Szkuta G. 2002. First record of Phytophthora ramorum in Poland. Phytopathol. Pol. 25: 69-79.

Ptaszek M., Orlikowski L.B. 2010. Zagrożenie niektórych roślin w szkółkach pojemnikowych przez gatunki Phytophthora wyizolowane z bylin. Zesz. Probl. Post. Nauk Rol. 554: 189-194.

Yoshimura M.A., Uchida J.Y., Aragaki M. 1985. Etiology and control of poinsettia blight caused by Phytophthora nicotianae var. parasitica and P. drechsleri. Plant Dis. 69 (6): 511-513. 